\title{
PHENOMENON OF ARCHITECTURE AND ITS PEDAGOGICAL IMPLICATIONS / RESEARCH PROBE: PATHS
}

\author{
Pavla Gajdošíková \\ Department of Art Education, Pedagogic Faculty, Charles University / Ph. D student (Czech Republic)
}

\begin{abstract}
The research study "Paths" was realized as a workshop in October 2018 at the Department of Art education, Pedagogic Faculty, Charles University, Prague, Czech Republic. This study is part of ongoing outcomes of author' doctoral studies. The subject of the study is the mutual interaction and overlap between architecture, art, and art education, and the common "language" shared by these fields. The main research tool is the collection of students' verbal and artistic statements, which help the researcher to understand the influences and relationships that help to shape young people's attitudes towards the phenomenology of architecture. Its objective is to investigate this phenomenon through artistic creation mediated to students and to explore the possibilities of using the findings of the creative processes in educational situations with university students. The applied methodology is related to the research of artist and designer creation: A/r/tography. Contemporary art education is based on visual literacy and critical thinking skills by integrating contemporary art into the core curriculum. It emphasizes inquiry-based education, a critical understanding of contemporary art practices, problem-solving, examining the relationship between art and relevant cultural and social issues. The development of creativity (creative process, creative (artistic) expression) and cultural heritage (art history, architecture, artistic traditions) are on the main trends of topical researches in art education that currently predominate in the world.
\end{abstract}

Keywords: Architecture, creative reflection, experience interpretation, methods in pedagogy, spatial forms.

\section{Basic characteristics and project objectives: Project rationale}

Architecture is art of the articulation of spaces. Architectural history has been written implicitly adhering to the rudimentary version of the model of communication. All the attention has been focused on the design of new forms but none of their interpretation. It is high time we realize that there should be a history of meanings along with a history of formation.

The Project is based on the current public discussions about how architecture influences our perception of public space, and the quality of life in our country connected with it (Melková, 2013).

However, the topic of architecture is almost absent at schools and in teacher training programs in the field of arts. In my experience such discussions take place only exceptionally in elementary and junior high schools, and unfortunately also at secondary schools, colleges and universities. The urgent need for change is called for e.g. by Elisabeth Gaus - Hegner, a German educationalist with five years' experience of teaching architecture to children, with focus on art didactics, she underpins the importance of paying attention to this topic already in childhood. According to her findings, it is very important to mediate architecture to children; it means to deliberately open the way for them to experience and get acquainted with space. (Gaus - Hegner, 2009).

\section{Research probe "Paths" - Implementation}

The Research Probe "Paths" was implemented in October 2018 as a probe of participatory type at the Department of Art education, Pedagogic Faculty, Charles University, Prague, Czech Republic in cooperation with Jan Pfeiffer, a Czech researcher artists and educator. Whole 180 minutes were devoted to it in the framework of painting. The sample chosen for the research were 12 students aged $19-24$ years. 
The Project's points of departure became part of a deeper investigation on how attitudes, values, opinions and their possible changes are structured. It took place at joint sessions of the teaching artist with the students over the topic of apprehending and experiencing architecture and space. The students were invited to cooperation and co-creation.

The research probe analysis took place in several steps and had the form of responding to research questions, which were asked one by one during the course of the research.

The lecture was documented by video camera and by written reflection by students, artists and an independent observer.

\section{Research theoretical postulates}

The resulting documentation became part of a folder containing reflective evaluation and artistic solution variants. Combinations of specific forms of qualitative and art-based research were exploited in the project (Fulková, 2008).

In theoretical postulates we focus mainly on the semiotic concept of art education. In art education, semiotics is a powerful concept, which can be used to revise traditional educational processes; it has strong impact on the topics, focus of the study, and the research method itself. (Fulková, Tipton, 2008).

Structuralism seems to have obvious application to the world of architecture through the disciplines of semiotics. Semiotics offers a mechanism by which the built environment can be read or decoded. It deals not only with the most obvious signs of our environment, but also how we think and act with signs, how signs penetrate into our penetrate into our innermost essence and determinate our existence.

In our case we applied methodology related to the research of artist and designer creation (art-led and practice-based research, artography) $\mathrm{A} / \mathrm{r} /$ tography is a research methodology, a creative practice, and a performative pedagogy that lives in the rhizomatic practices of the liminal in-between (Irwin, 2004).

Especially the reflective-practice concept of Donald A. Schön was used for our probe. This approach, which arose from Schön's observations of students of architecture, is a reflection on learning as a tool of gaining knowledge everywhere, where the linear learning model fails, and expert knowledge is torn from practice; he also vindicates the implicit tacit knowledge of the practitioners. (Schön, 1983).

\section{Research problem - Research questions}

The research probe analysis took place in several steps and had the form of responding to research questions, which were asked one by one during the course of the research.

1. What are the existing attitudes of Czech students to architecture and other forms of spatial art?

2. Can these attitudes be changed during the joint meetings of the teaching artist and students over the phenomenon / topic of architecture?

3. What are the phenomena students focus on when perceiving their inner and outer lived space? What and how they speak about it? Which are the phenomena they mention most frequently?

\section{Summary of findings from the realized survey}

I investigated this phenomenon based on A/r/tografy methodology and we came to the following findings. The findings confirm the ideas of the educator and researcher Jan Slavík, who identified several points of similarity and congruence between art and education: a delimitation of space and time, composition, and the beauty of the work. (Slavík, 1996).

This fact refers to the overall understanding of the realized $\mathrm{A} / \mathrm{r} / \mathrm{t} /$ ographic educational model, in which the artist/teacher/researcher works in a kind of "third world" where his various identities become intertwined and begin to influence one another.

Having verified these research findings, we can draw the following conclusions:

The subjects, which were approached from the viewpoint of several different "situations," are assessed identically, with just minor deviations. The study's participants perceive and experience this space or architecture very intensively on the basis of their own positive or negative experiences. We may take it as proven that perception influences how we interpret the world, but also that the opposite is true: our interpretation of the world plays a role in how we perceive a particular place. The criteria for evaluating architecture are thus associated with this experienced phenomenon. 


\section{Conclusion}

Based on our research probe findings we arrived at the following conclusion:

This topic is highly relevant and inspiring both for an art teacher and artist, making it almost a must for him to deal with it as part of his professional practice, thus handing his or her experience further again.

Contemporary art education in the narrow sense means the place of contemporary art and architecture in art education and its teaching strategies. The contemporary cultural context and the spread of visual culture provide preconditions for changes in art education. To understand the meaning of contemporary art education is important to examine the meaning of contemporary education. Educational reforms are associated with new learning environments, changing students attitudes towards learning and teaching, the changing roles of an educator in the process of education. (Sederlhorn, 2012).

We arrived at a conclusion that investigating phenomenology of architecture in connection with the semiotic concept of art education is indispensable both for the teaching artist and the student. We deem it is a perpetual task of architecture to create an existential metaphor that gives our being in the world concrete shapes and structure. Architecture reflects upon, materializes and immortalizes ideas and images of an ideal life. Space and our perception of it make us capable of structuring and also understanding the shapeless flow of reality and last but not least to realize what we are. (Norberg- Schulz, 1980).

There will be a follow-up to the "Paths "research probe, in the form of other research probes' analyses, namely "Memory of the Place" and "My Home". The research findings are meant for art teachers and students at teacher training institutions. We see the contribution of our research for the art education theory in verifying the functionality of the new methodology in a concrete educational environment and with concrete findings that can be used in teaching practice.

\section{Acknowledgements}

The Research Project Phenomenon of Architecture and Its Educational Implication was supported by the Charles University Grant Agency (GAUK No. 250357) and has been carried out at the Charles University Prague, Faculty of Education. This text is part of preparatory studies for the topic of visual literacy, supported by the research program of Charles University Progress Q17.

\section{References}

Fulková, M, Tipton, T. (2008). A (Con)text for the New Discourse as a Semiotic Praxis. The International Journal of Art and Design Education, 27 (1).

Fulková, M. (2008). Diskurs uméní a vzdělávání / The Discourse of Art and Education. Jinočany: H \& $\mathrm{H}$ Fulková, M. (2008). Diskurs umění a vzdělávání / The Discourse of Art and Education. Jinočany: H \& H

Fulková, M., et al. (2013). Muzejní a galerijní edukace / Museum and Art Gallery Education 2. Učení z umění / Learning from Art. Educational Programs of the Museum of Decorative Arts in Prague and Rudolfinum Art Gallery 2012 and 2013. Prague: Charles University, Faculty of Education and Museum of Decorative Arts in Prague,

Gaus - Hegner, E. (2009). Raum erfahren - Raum gestalten: Architektur mit Kindern und Jugendlichen, Taschenbuch.

Irwin, R. (2004). A/R/Tography: Rendering Self Through Arts-Based Living Inquiry, Vancouver, Canada: Pacific Educational Press

Melková, P. (2013). Proživat architekturu / Experiencing Architecture. In Řevnice: Arbor vitae.

Norberg - Schulz Ch. (1980). Genius Loci, Towards a Phenomenology of Architecture, Rizzoli: New York

Schön, D. (1983). Reflective Practitioner. How Professionals Think in Action. New York: Basic Books.

Sederholm H. (2012). Artbeat. Helsinki: Aalto Art Books 